\title{
Recrystallization Behavior of Titanium and Its Alloys
}

\section{1. 緒言}

純チタンは室温で稠密六方晶 ( $\alpha$ 相) であるが $882^{\circ} \mathrm{C}$ 以上では体心立方晶 $(\beta$ 相) に変態する.これに対して チタン合金では添加元素の種類および量によりこの変態 温度 ( $\beta$ 変態点) が変化するとともに, 室温における相 状態も変化し $\alpha$ 型, $\alpha+\beta$ 型および $\beta$ 型の 3 種類に大 別される. $\alpha$ 型チタン合金は状態図に沶いて $\alpha$ 相領域 を拡大させる元素 ( $\alpha$ 安定化元素 $; \mathrm{Al}, \mathrm{C}, \mathrm{O}, \mathrm{N}$ など) を含有して拈り室温において $\alpha$ 単相でありその組織は 純チタンとほぼ同じである。 $\beta$ 型チタン合金は $\beta$ 相領 域を拡大させる元素 ( $\beta$ 安定化元素; Mo, V, Fe, Cr, $\mathrm{Mn}$ など）を含んで拈り室温で $\beta$ 単相である. $\alpha+\beta$ 型合金は一般に上記 2 種類の元素を含んでおり，室温で $\alpha$ 相および $\beta$ 相が共存するとともに熱処理条件によつ てミクロ組織の形態を種々変化させることができる. 合 金の機械的性質はミクロ組織によつて左右されることか らミクロ組織におよぼす加工・熱処理条件の影響を把握 しておくことが重要である.

本稿では純チタン, $\alpha+\beta$ 型および $\beta$ 型チタン合金 の再結晶挙動について述べる.

\section{2. 純チタンの再結晶挙動}

\section{1 $\boldsymbol{\alpha}$ 相温度域における再結晶}

十分に加工された純チタンの軟化曲線を図 1 に示す。 再結晶開始温度は約 $450^{\circ} \mathrm{C}$ であり, この温度以上でか $\supset \beta$ 変態点 $\left(882^{\circ} \mathbf{G}\right)$ 以下の温度に加熱すると写真 1 に 示すよらな方向性のない等軸の再結晶組織が得られる. 純チタンは主として酸素含有量により強度レベルを調整 するが，酸素含有量が増加すると再結晶温度は上昇す る. 再結晶温度以上に加熱すると粒成長が起こる. その ときの平均結晶粒径は加熱時間に対して放物線則に従い 加熱時間のほほ $1 / 3$ 乗に比例する ${ }^{1)}$. また温度に対して はArrhenius の式に従い結晶粒成長のための活性化エ ネルギーは, 酸素含有量の増加とともに低下するが, 通
Takashi Nishimura and Masahito Fukuda

常の工業用純チタン（酸素含有量 $400 \sim 3000$ ppm) では 40〜 $55 \mathrm{kcal} / \mathrm{g}$-atom 程度である1). すなわち高温ほど結 晶粒径は大きくなるが， $850^{\circ} \mathrm{C}$ 以上になると逆に結晶粒 が微細化する場合がある。その例を図 2 亿示す。これは

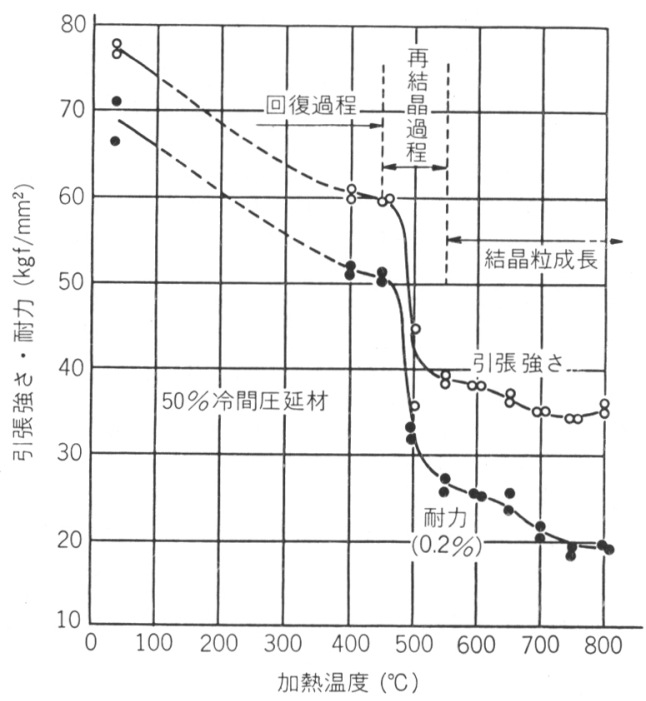

図 1 純チタンの軟化曲線

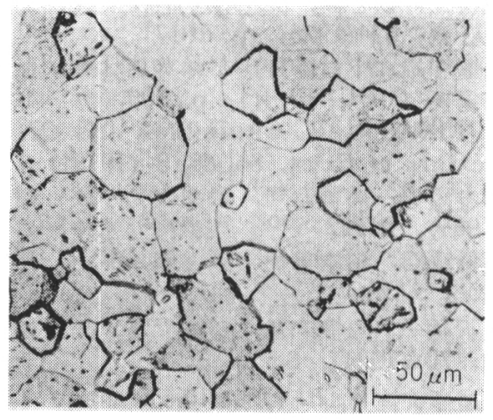

写真 1 純チタンの $\alpha$ 域加熱材の組織 昭和 59 年 3 月 14 日受付 (Received Mar. 14，1984)（依頼技術資料)

* (株) 神戸製鋼所中央研究所工博 (Central Research Laboratory, Kobe Steel, Ltd.)

*2 (株) 神戸製鋼所中央研究所 (Central Research Laboratory, Kobe Steel, Ltd., 1-3-18 Wakinohama-cho Chuo-ku Kobe 651) 


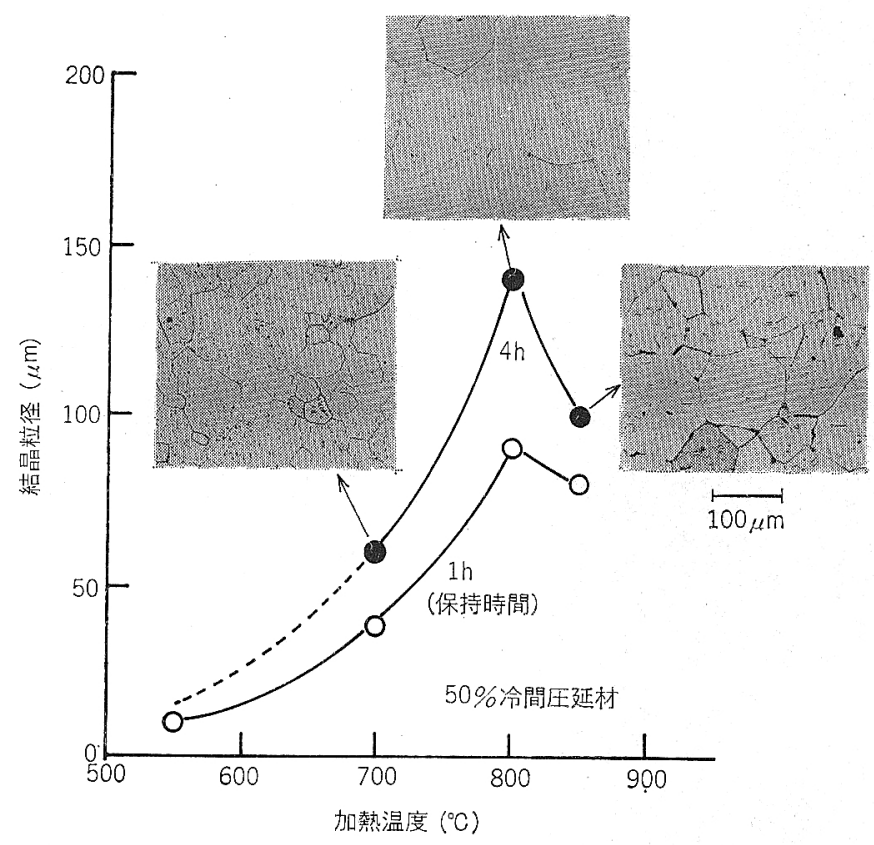

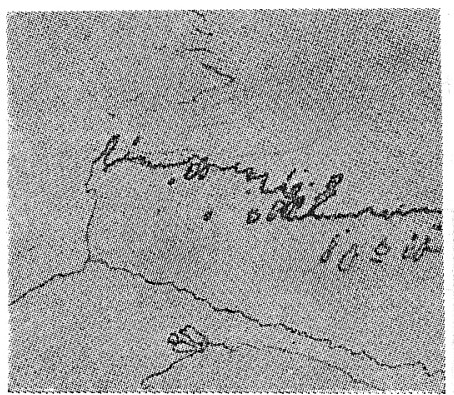

急冷 (鋸歯状)

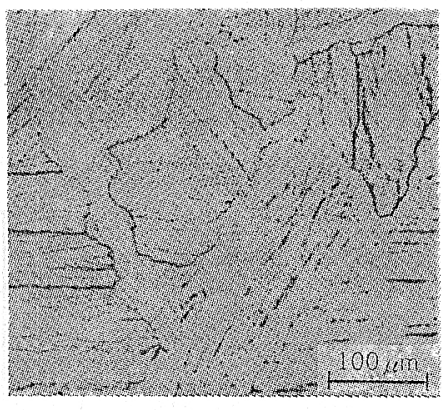

炉冷 (針状)
図2純チタンの粒成長挙動
写真 2 純チタンの $\beta$ 域加熱材の組織
工業用純チタンが共析型 $\beta$ 安定化元素である $\mathrm{Fe}$ を不 純物として含有する（通常 $2000 \mathrm{ppm}$ 以下）ためで， $850^{\circ} \mathrm{C}$ 以上になると $\beta$ 相が析出し $\alpha$ 粒の成長を抑制 するためと考光られる. 純チタン板の成形性は結晶粒径 により大きく変化する2ためそのような目的の場合には 上述した粒成長挙動を考慮して最適な熱処理条件が選ば れる。

\section{2 $\beta$ 相温度域における再結晶組織}

等軸組織は $\alpha$ 相領域で加工して再結晶させたとさに 得られるが， $\beta$ 域 $\left(882^{\circ} \mathrm{C}\right.$ 以上) に加熱して冷却和ると まつたく異なつた組織になる。气の例を写真 2 に示す。 これは加熱時の $\beta$ 相(このとさは等軸の $\beta$ 粒が形成さ れている）が泠却中に $\alpha$ 相に変態するためで, 冷却速度 によつて鋸歯状あるいは針状の組織になる。このような 組織になつても機械的性質は等軸組織材とほとえど変わ らないが延性がいくらか低下する゙)ため通常は等軸組織
材が使用される。

\section{3. $\alpha+\beta$ 型チタン合金の再結晶挙動}

$\alpha+\beta$ 型合金は添加元素の種類と量により $\alpha$ および $\beta$ 相の量比が変化し, 特性も大きく変化するために合金 の種類がもつとも多い. 代表的なものが Ti-6Al-4Vで あり，すぐれた強度と延性の組み合わせを有するととも に，加工や溶接などの製造性においてもすぐれているた めもつとも多用されている， $\alpha+\beta$ 型合金は 2 相が共存 するため熱処理条件によつてミク口組織が複雑に変化す る.ここでは Ti-6Al-4V を例にとの特徴について述べ る.

\section{1 ミクロ組織におよぼす溶体化条件の影響}

$\alpha+\beta$ 型合金においては $\alpha+\beta$ 域で加工して等軸組織 にした後 $\beta$ 変態点 (Ti-6A1-4V では約 $995^{\circ} \mathrm{C}$ ) 以下の 高温域で溶体化処理を行い，その後より低い温度で時効 

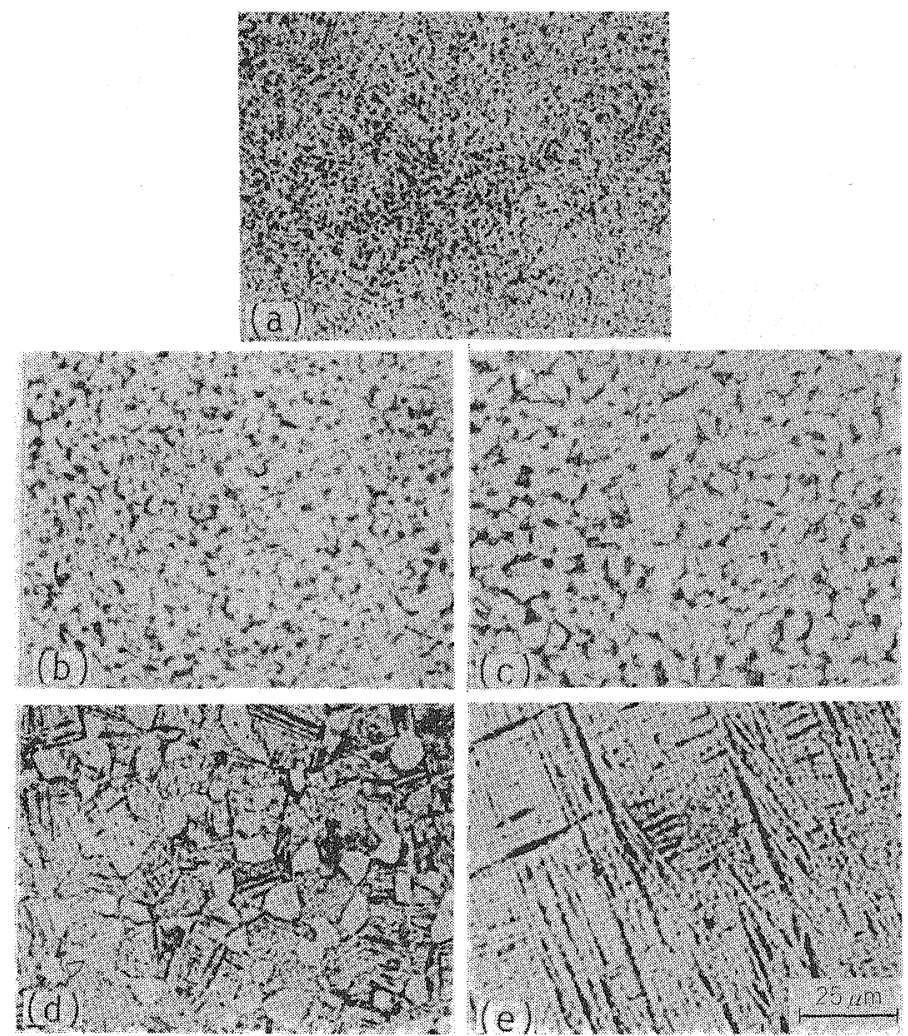

（a）素材 (b) $850^{\circ} \mathrm{C}$ 啵体化 (c) $900^{\circ} \mathrm{C}$ 溶体化 (d) $950^{\circ} \mathrm{C}$ 寀体化 (e) $1000^{\circ} \mathrm{C}$ 溶体化

写真 3 Ti-6Al-4V のミクロ組織におよ 添す溶体化処理埧度の影響
するのが一般的な熱処理法で方る。その場合得られるミ ク口組織は溶体化処理条件によつて変化する．写真 3 に ミク口組織に和よ注す溶体化温度の影響を示す。和い

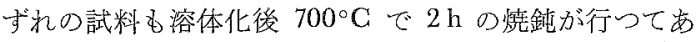
る. 素材は $99 \%$ 以上の加工を受けた圧延棒できわわて 微細な等軸 $\alpha$ 組織を有している。ここで白色部が $\alpha$ 相 で等り黑色部が $\beta$ 相で多る. $\alpha+\beta$ 域に和いては溶体化 温度の上昇にともない素材の等䩜 $\alpha$ 粒 (初析 $\alpha$ 粒) 成長するとともに初析 $\alpha$ 粒間には細長い針状の組織が 形成されるよらになる。この針状組織部心溶体化温度に 保持したとき $\beta$ 相であつた領域であり，その後の椧却 と焼䤶によつて生成したもので針状 $\alpha$ 相 (白色部)とそ の粒界 $\beta$ 相（黒色部）とから構成されて拈り，初析 $\alpha$ 粒と区別する意味でここでは変態 $\beta$ 組織と呼ぶ。溶体 化温度が $1000^{\circ} \mathrm{G}$ と $\beta$ 域になると変熊 $\beta$ 組織が 100 $\%$ になる.初析 $\alpha$ 粒の粒成長について田上ら は平均 結晶粒径が加熱時間の㴗ぼ $1 / 4$ 乗に比例することおよ びその活性化エネルギーが $56 \mathrm{kcal} / \mathrm{g}$-atom と純チタン の場合より粒成長しにくい結果を報告している。これは 上述した变態 $\beta$ 相の生成と成長により初析 $\alpha$ 粒の成長 が抑制されるためと考光られる。写真 3 のミタ口組織を 有する材料の張り性質を図 3 亿示寸。强度は $850^{\circ} \mathrm{G}$ の溶体化処理によりいらたん低下するが溶体化温度の上 昇之ともに増加し $975^{\circ} \mathrm{C}$ で最大值杂している. 延性

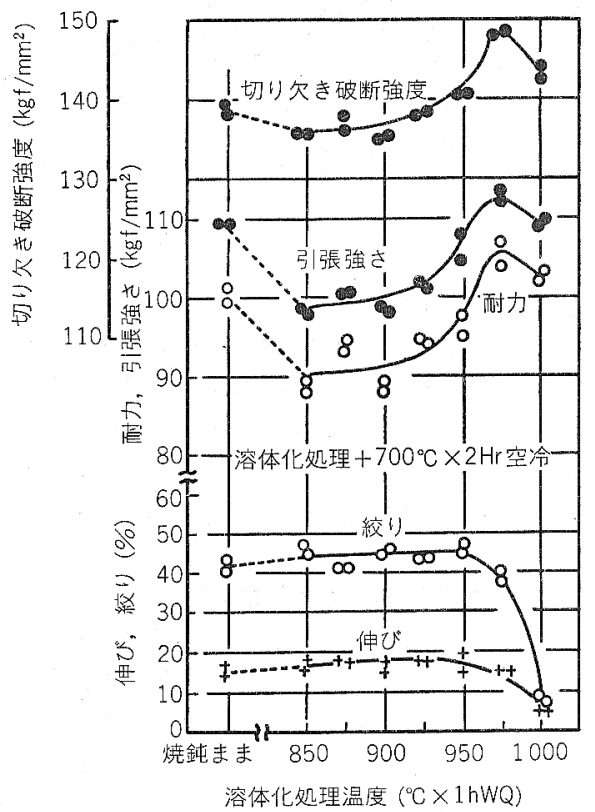

図 3 Ti-6Al-4V の機械的性質におよぼす溶体化 処理温度の影響 


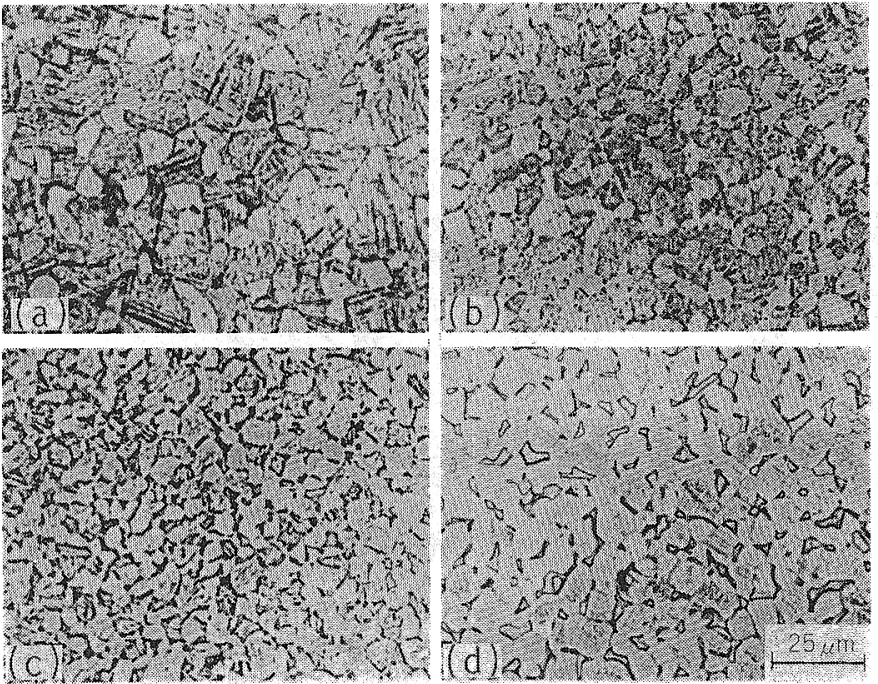

（a）承冷 (b) 泊冷 (c) 空冷 (d) 胡冷 写真 4 Ti-6Al-4V のミク口組織に打よ ぼ寸溶体化処理後の冷却速度の影䏤
は溶体化温度 $950^{\circ} \mathrm{C}$ まではほとんと変化しないか高温 ほどわずかに上昇する程度であるが， $\beta$ 域の $1000^{\circ} \mathrm{C}$ になると伸び，絞りともに 10\% 以下に低下している。 以上のことから $950^{\circ} \mathrm{C}$ 付近で溶体化処理を施すことに より强度と延性の最適な組み合わせが得られることがわ かる、なお素材に扣いてすぐれた機械的性質を示してい るがこれは微細な等軸組織を有するためである。しかし 鍛造加工のよらに $\alpha+\beta$ 域に拈ける加工と熱処理が不十 分になりやすい場合は粗大な等軸 $\alpha$ 組織となり強度打 よび延性のいずれす低下する場合がある。したがつて溶 体化処理前の履歴にかかわらず安定してすぐれた機械的 性質が得られるのは初析 $\alpha$ 相拉よび変態 $\beta$ 相が共存し た（初析 $\alpha$ 相量が $10 〜 40 \%$ ) 組織の場合である.

溶体化処理・焼鈍後のミク口組織に打よ洼す溶体化処 理直後の冷却速度の影響を写真 4 に示す. 冷却速度が速 い渒ど初析 $\alpha$ 粒が小さく，変態 $\beta$ 相が多くなるととも にその中に存在する針状 $\alpha$ 相が微細になることがわか る.これらの材料の機械的性質を図 4 に示すが冷却速度 が速いほどすぐれた強度と延性が得られることがわか る。また素材に执いて高強度を有するのは図 3 の場合と 同様微細な等軸組織のためであり，溶体化処理により初 析 $\alpha$ 粒が粗大化する之強度は低下寸る. しかし写真 4 の急冷 (WQ) 村のように初析 $\alpha$ 粒がある程度大きく なつても微細な変態 $\beta$ 組織が $50 \%$ 以上存在すると素 材の微細な等軸組織と同等の高強度を示すよらになる.

ところでチタン合金が航空機エンジン部材として使用 される場合，機杫的性質としては引張り，疲労，クリ一 プ強度および破壊じん性などが重要視される。チタン合 金に执いては，一般に引張性質および低サイクル疲労に は等軸組織が，クリープ強度和よび破壞じん性には針状 組織がすぐれている5゙，筆者らは引張性質扣よび破壊で え性に和よぼす組織の影響を定量的に評価し6)7)，微細な

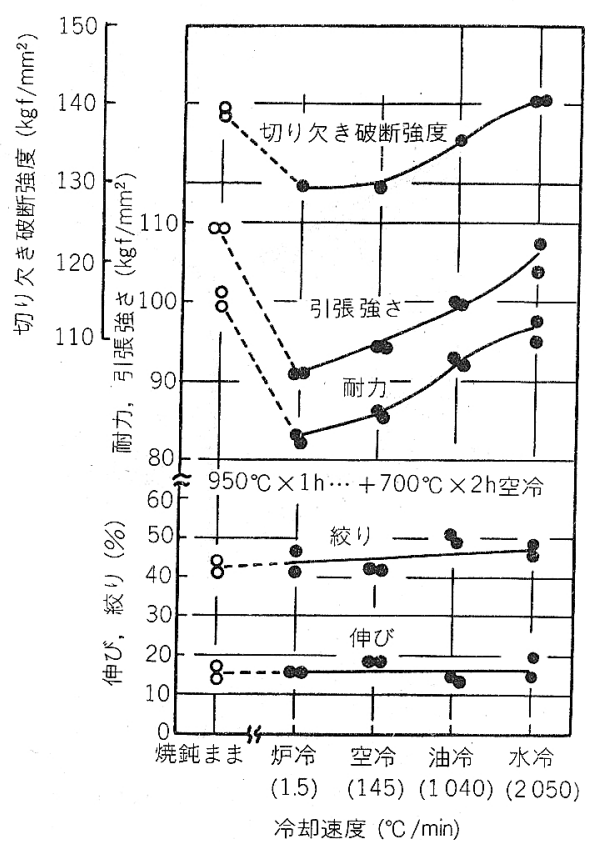

図 $4 \mathrm{Ti}-6 \mathrm{Al}-4 \mathrm{~V}$ の機械的性質におよぼす溶体化 処理後の冷却速度の影響

初析 $\alpha$ 相と変態 $\beta$ 相の共存した組織が強度, 延性利よ びじん性のいずれをも満足させるのに効果的であること 明らかにした。すなわら微細な初析 $\alpha$ 組織により高 い強度と延性が，また釗状の変態 $\beta$ 組織により高いじ 几性が得られるためである。この場合溶体化処理前にい つたん等軸組織にしておくことが必要となる。またその 等草組織尼微細なほど好ましい。

\section{2 針状組織の等軸化}

$\beta$ 域で加工方るいは加熱されて形成されてた針状組織は 

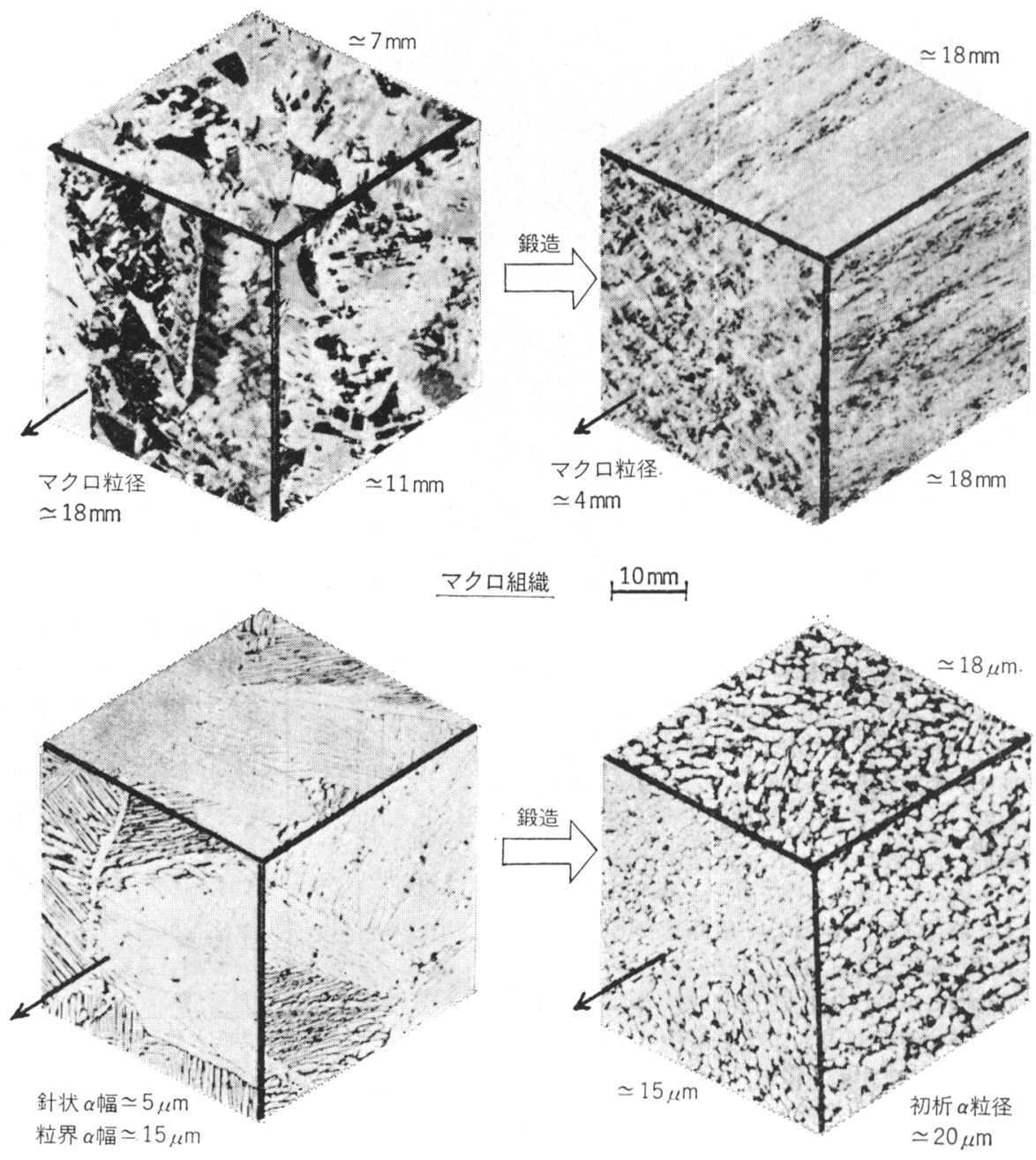

ミク口組織

(a) 鋳 塊

(b) 鍂造後

军真 $5 \mathrm{Ti}-6 \mathrm{Al}-4 \mathrm{~V}$ 鋳塊の鍛造によるマクロおよびミクロ組織の变化

$\alpha+\beta$ 域で加工することにより等軸化させることができ る. 針状 $\alpha$ 粒の幅と長さの比を等軸化率と定義( 1 のと き完全な等軸となる) し，それと $\alpha+\beta$ 域にお忛る加工 量との関係を図 5 に示す. 図 5 より $\varepsilon=1.5$ (鍛造比に すると 4.5) 以上の加工によりほ洔軸化することがわ かる.鋳塊を $\beta$ 域および $\alpha+\beta$ 域で鍛造（鍛造比はそ れぞれ 2.0 および 1.7) した後の組織を写真 5 に示す。

ミク口組織において鋳塊の針状組織は粒状に等軸化して いる. いつぽら初析 $\alpha$ 粒径は 15〜20 $\mu \mathrm{m}$ とまだ十分微 細化していないとともに鋳塊のマクロ組織 (前 $\beta$ 粒) む 十分微細化せずに残存している.

\section{3 ミクロおよびマクロ組織の微細化}

加工量が多い汪ど組織が微細になるのはチタン合金に おいても同様であるが通常の鍛造加工においては写真 3 に示した素材のような微細組織にし得るほどの加工量を 確保するのは容易でない.さらに写真 5 に示したように 鋳塊のマク口組織も容易に消失しない。このような場合 $\beta$ 域加熱処理 ( $\beta$ 処理) を行らことがきわめて有効であ る. その例を図 6 に示す. 素材は $\beta$ 処理前の $\alpha+\beta$ 鍛 造量を変えてあるものの写真 5 の (b) とほぼ同じマク口 およびミクロ組織である. 図 6 から短時間の $\beta$ 処理に よりマクロ粒（前 $\beta$ 粒） は約 $1 / 10$ に微細化されると 
ともに $\beta$ 処理前の $\alpha+\beta$ 域にお汀る加工量あるいは $\beta$ 処理温度の影響をあまり受けないことがわかる. $\beta$ 処理 前の加工ひずみのため $\beta$ 域加熱時に再結晶核が多く発 生して微細化すると考兄られる.

写真 5-(b) 材に対してこのような $\beta$ 処理を施したと ころ方向性のあるマクロ組織が消失するとともにマクロ 粒は $0.4 \mathrm{~mm}$ にまで微細化した. その後 $\alpha+\beta$ 域で鍛 造したところマクロ粒はさらに微細化し, 写真 6 に示す ように約 $0.2 \mathrm{~mm}$ になつた. またミクロ組織において 8 $\beta$ 処理前に 15 20 $\mu \mathrm{m}$ であつた初析 $\alpha$ 粒は $\beta$ 処 理前と比較してさらに等軸化が進むとともに 7〜8 $\mu \mathrm{m}$ の大ささにまで微細化した。

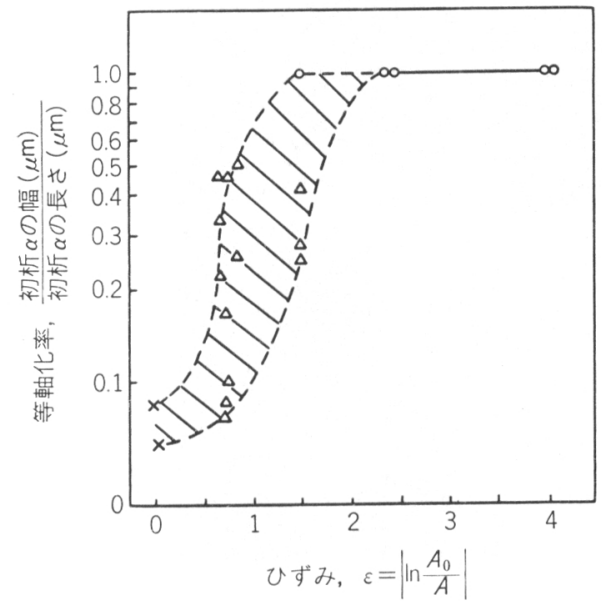

図 5 Ti-6Al-4V における針状 $\alpha$ 粒の等軸化と $\alpha+\beta$ 域加工量の関係

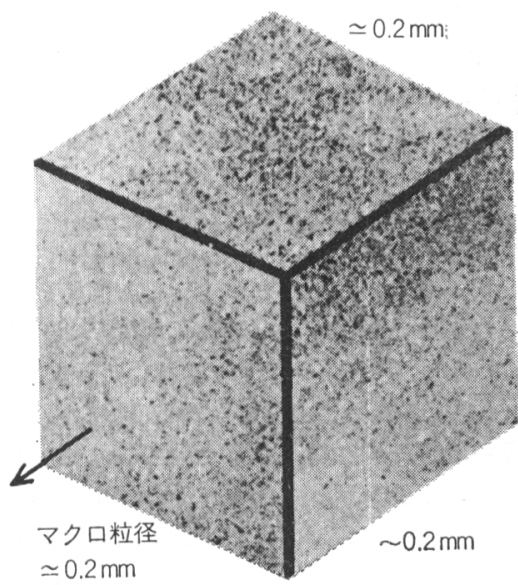

マクロ組織
以上のように鋳塊からの加工・熱処理条件を適切に選 ぶことにより微細な等軸 $\alpha$ 組織が得られ，3.1 節で述 ベた溶体化・焼鈍処理を付加することにより強度，延性 およびじん性のすぐれた材質を得ることが可能になる.

\section{4. $\boldsymbol{\beta}$ 型チタン合金の再結晶挙動}

工業合金として開発された $\beta$ 型合金はいずれも室温 に拈ける平衡状態では $\alpha+\beta$ の 2 相であるが, 比較的速 く泠却することによつて $\beta$ 相を残留させている準安定 相の合金である.したがつて $\alpha+\beta$ 型合金と同様の溶 体化時効処理を行らと $\alpha$ 相が析出して高い強度を得る

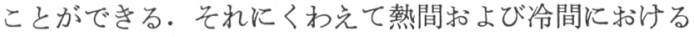
加工性がすぐれているため近年特に注目されている.こ こではすぐれた耐食性をも有している Ti-Mo 系 $\beta$ 合 金について再結晶組織の特徵を述べる.

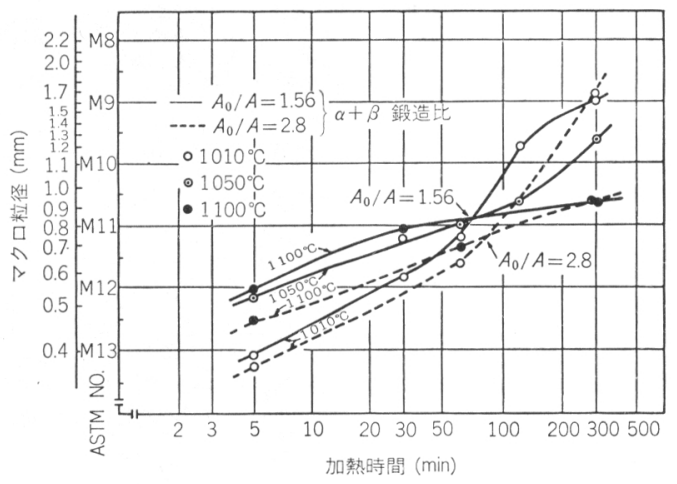

図 $6 \mathrm{Ti}-6 \mathrm{Al}-4 \mathrm{~V}$ のマクロ粒径におよぼす $\beta$ 処理 条件の影響

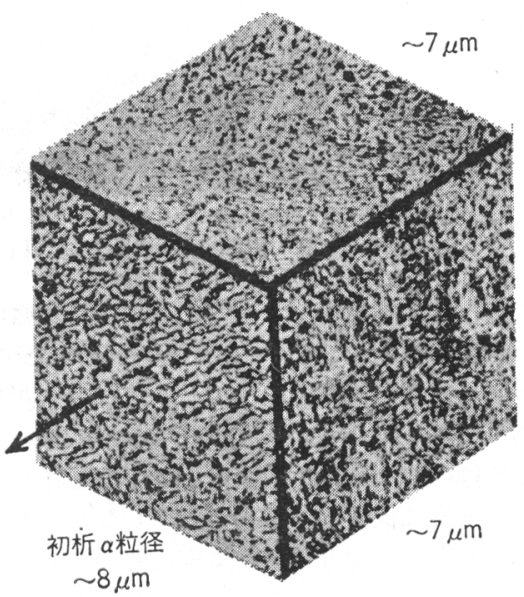

ミクロ組織

写真 $6 \beta$ 処理材における鍛造後のマクロおよびミクロ組織（写真 5 の鍛造材を $\beta$ 処理後 $\alpha+\beta$ 鉎造） 


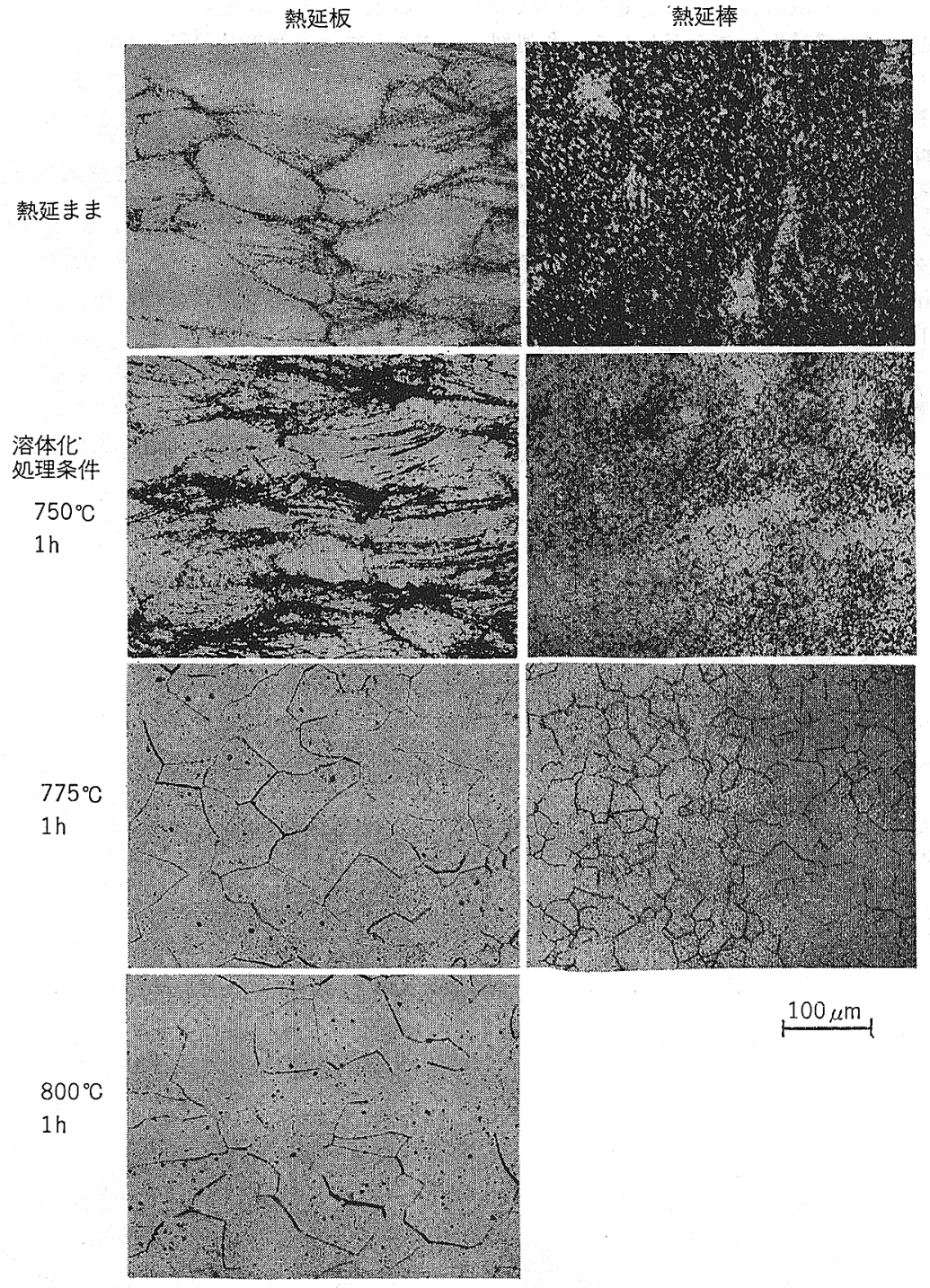

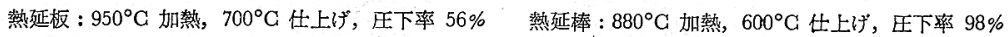

写真 7 初期組織の異なる Ti-15Mo-5Zr 溶体化処理材のミク口組織

初期組織の異なる 2 種類の Ti- $15 \mathrm{Mo}-5 \mathrm{Zr}$ ( $\beta$ 变態点 $730^{\circ} \mathrm{G}$ ) を各種温度で溶体化処理 (各温度に保持後急冷) した場合のミクロ組織を写真 7 亿示す。いずれも $775^{\circ} \mathrm{G}$ 以上で等軸の $\beta$ 粒に再結晶している. 本合金に洛いて

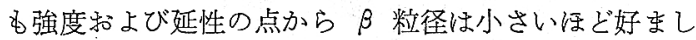
(7)ので溶体化温度は低温活ど望ましい，したがつて写 真 7 からるかかように初期組織は微細なほど有利であ る. 溶体化処理後 $500^{\circ} \mathrm{G}$ で 100 分時効した後の組織を 写真 8 亿示卞。广括 $500^{\circ} \mathrm{G}$ という時效温度は本合金に 执いて $\alpha$ 相が最も多く析出する温度で苏る ${ }^{8}$ 。写真 8 飞扒いて溶体化温度が低い場合は黒色粒と白色粒が漉在 する不均質な組織であるのに対し，溶体化温度が高くな
ると均一になることがわかるそそして時効後の組織が均 一になるのは熱延板では溶体化温度が $825^{\circ} \mathrm{G}$ の場合で あり，熱延棒では $775^{\circ} \mathrm{C}$ と素材により異なつている(イ ンゴットは同一であり以降の加工履歴の及变えてある). 黒色粒は優先的に腐食された粒で $\alpha$ 相が優先的に析出 していることを示している。年の理由は Ti-Mo 系合金 飞乱いて $\alpha$ 相は Mo 量が少なく耐食性が劣るからで㘯 る.

結晶粒によつて $\alpha$ 相が析出しやすいわのとそうでな いものがあることは写真 7 和よび 8 の結果から次のよう に考えることができる.再結晶の核は塑性変形により導 入さ机たひずみや欠楩の集中したところから生じ，塑性 


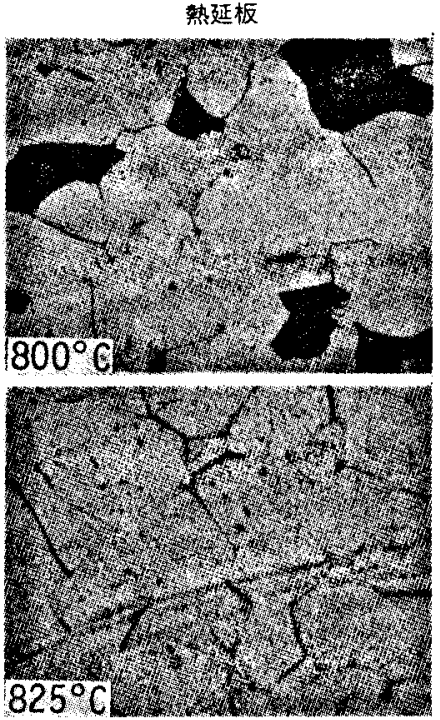

$825^{\circ} \mathrm{C}$

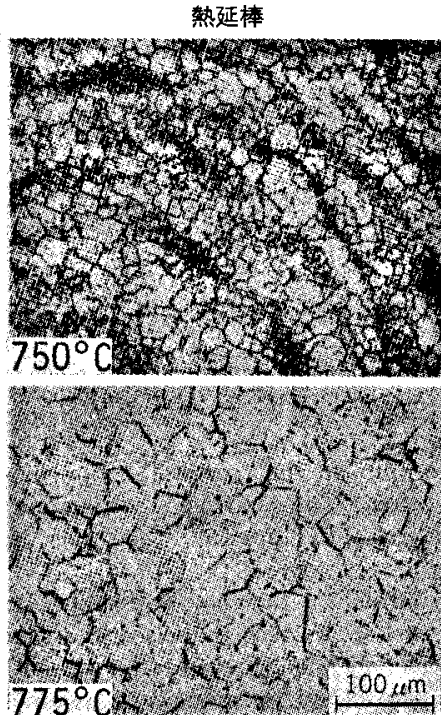

表示湿度 : 溶体化処理温度

写真 8 溶体化処理後 $500^{\circ} \mathrm{C}, 100 \mathrm{~min}$ 時妨処理した $\mathrm{Ti}-15 \mathrm{Mo}-5 \mathrm{Zr}$ のミクロ組織
変形量が大きいほど再結晶核は多く生成するとともに低 い温度で再結晶が開始する，写真 7 の初期組織をみると 熱延板は熱延棒と比較するとはるかに 粗大な 結晶粒を 有している.したがつて熱延板ではいずれの粒も变形は しているもののひずみ（貯えられているひずみエネルギ 一）および久陷稒々の粒によつて大きな差があるすの と予想される，その場合大きなひずみあるいは多くの欠 陥を有している粒が優先的に，より低い温度で再結晶す ると考えられる。すなわり熱延板の $775^{\circ} \mathrm{C}$ 溶体化まま 材においてはあたか子再結晶が完了しているようにみえ るが，新しく再結晶した粒とひずみおよび欠宿の少ない

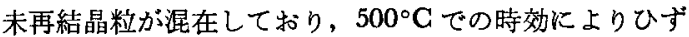
み拈よび久循が残留している後者の粒において優先的に

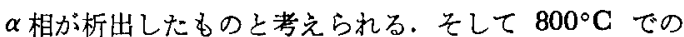
溶体化処理によりはじめてすべての結晶粒が再結晶を完 うしたため時効後の $\alpha$ 相の析出が均一になつたものと 推定される.

いつぽう熱延棒においては熱延板よりも低温で強加工 を受けているため組織が微細であるとともにすべての粒

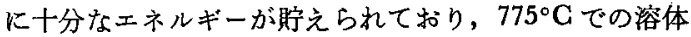
化処理により再結晶が完了したものと考えられる.

以上のよらに Ti-Mo 系 $\beta$ 合金に扎いては加工履歴 に起因する初期組織によつては溶体化処理時に 2 段階の 再結晶過程が存在することを示した．このような 2 段階 の再結晶過程をとる場合は，その段階によりみかけの再 結晶状態は同じであつても，機械的性質が変化するきの で注意することが必要である。また本稿ではふれなかつ たが Ti-Mo 系合金においては時效温度が低いと $\beta \rightarrow \alpha$ 変態時の中間相である $\omega$ 相が析出して脆化するので最
適な時効条件を選ぶことが重要である8).

\section{5. 結}

純チタン, $\alpha+\beta$ 型执よび $\beta$ 型チタン合金における再 結晶の特幑について説明した.チタンおよびチタン合金 においては単に熱処理のみでなく加工と熱処理の組み合 わせがミクロ組織および機械的性質なとの材質に大きな 影響を与えるため，それらの相互関係を明確にしておく ことが必要である。特に $\alpha+\beta$ 型合金 (Near $\alpha$ 打よ び Near $\beta$ 合金を含む)に括ける等軸蛙よび針状組織の 挙動あるいは $\alpha$ 相と $\beta$ 相およびそれらの境界層の特性 についてはいまだ十分に解明されたとはい方，今後の 研究によりさらにすぐれた加工・熱処理が見出されるこ とが期待される。

\section{文献}

1) $K$. Okazaki, $K$. Morinaka and $H$. Conrad: Trans. JIM., 13 (1972), p. 198

2 ) 森口康夫, 長谷川 淳, 西村 孝, 谷口三男: 神 戸製鋼技報，32（1982），p. 24

3 ) 園井英一, 西垣 実: チタニウム・ジルコニウ ム, 22 (1974) 3, p. 143

4) 田上耕司, 岡崎謙二: 日本金属学会誌, 37 (1973), p. 535

$5 ）$ 金属チタンとその応用（「金属チタンとその応用」 編集委員会編) (1983)，p. 56 [日刊工業新聞社]

6) 西村 孝, 伊藤喜昌, 杉村 泰: 日本金属学会請 演概要 $(1972 \cdot 10$ 月), p. 129

7 ) 西村孝，伊藤喜昌: 日本金属学会講演概要 $(1973 \cdot 10$ 月), p. 322

8 ) 西村 䓔, 西垣 実, 大谷四㤵: 日本金属学会 誌, 40 (1976), p. 219

9 ) 大谷四眣，西垣 実：日本金属学会誌，36 (1972), p. 346 